\title{
PENGARUH KETERSEDIAAN SUMBER DAYA MANUSIA YANG MEMADAI DAN PERUBAHAN REGULASI TERHADAP HASIL KINERJA KARYAWAN PADA KANTOR KEPALA DESA DI KECAMATAN SAWAN
}

\author{
PUTU SEPTA ADI KUSUMA, KETUT EKA PRATAMA WIJAYA, KADEK VANNY \\ PANJI PUTRA, MADE ERIS DARMAYOGA, YUDHA ARYADI
}

Jurusan Akuntansi, Universitas Pendidikan Ganesha, Singaraja, Bali, Indonesia

\begin{abstract}
Abstrak
Penelitian ini bertujuan untuk mengetahui pengaruh ketersediaan kapasitas SDM dan personalia Kantor Kepala Desa di Kecamatan Sawan terhadap kualitas kinerja karyawan secara keseluruhan, dan bagaimana pengaruh perubahaan Regulasi Pagu Anggaran dari Kabupaten terhadap Anggaran yang telah disusun sebelumnya pada Kantor Kepala Desa di Kecamatan Sawan. Penelitian yang digunakan dalam penelitian ini adalah penelitian kuantitatif dengan metode observasi dan wawancara. Kualitas SDM dan Personalia dapat berpengaruh terhadap kinerja karyawan. Tingkat pengetahuan dan keahlian pegawai desa dalam menggunakan SISKEUDES masih kurang sehingga berpengaruh terhadap kinerja di kantor desa itu sendiri. Pengaruh tersebut berupa kurangnya keakuratan informasi yang dihasilkan SISKEUDES. Kemampuan pegawai yang masih belum mahir dalam dalam menggunakan SISKEUDES berdampak terhadap akuratnya data yang dihasilkan, sehingga dapat dikatakan bahwa kualitas SDM dan Personalia berpengaruh terhadap kualitas kinerja kantor kepala desa di wilayah Kecamatan Sawan.
\end{abstract}

Kata Kunci : Ketersediaan, Sumber Daya Manusia, Perubahan, Regulasi

\section{Abstract}

This research aims to determine the impact of the availability of human resources and village head office personnel in Sawan Sub-district to the overall quality of the employee's performance, and how the change in regulation of the Pagu fencing From the district to the budget that had been pre-arranged at the village head office in Sawan Sub-district. The research used in this study is quantitative research with observation and interview methods. The quality of human resources and personnel can affect employee performance. The level of knowledge and expertise of village officers in using SISKEUDES is still lacking, which affects the performance in the village office itself. This influence is the lack of accuracy of information generated by SISKEUDES. Ability of employees who are still not proficient in using SISKEUDES affect the accuracy of the resulting data, so it can be said that the quality of human resources and personnel influence The performance quality of the village head office in Sawan Sub-district.

Keywords: availability, human resources, change, regulation 


\section{Pendahuluan}

Pemerintah Desa adalah lembaga pemerintah yang bertugas mengelola wilayah tingkat desa. Lembaga ini diatur melalui Peraturan Pemerintah No. 72 Tahun $\underline{2005}$ tentang pemerintahan desa yang diterbitkan untuk melaksanakan ketentuan pasal 216 ayat (1) Undang Undang Nomor 32 Tahun 2004 tentang pemerintahan daerah. Pemimpin pemerintah desa, seperti tertuang dalam paragraf 2 pasal 14 ayat (1), adalah kepala desa yang bertugas menyelenggarakan urusan pemerintahan, pembangunan, dan kemasyarakatan.

Desa salah satu ujung tombak organisasi pemerintah dalam mencapai keberhasilan dari urusan pemerintahan yang asalnya dari pemerintah pusat. Perihal ini disebabkan desa lebih dekat dengan masyarakat sehingga program dari pemerintah lebih cepat tersampaikan. Desa mempunyai peran untuk mengurusi serta mengatur sesuai dengan Undang-Undang Nomor 6 Tahun 2014 tentang Desa yang salah satu pasalnya dijelaskan bahwa desa memiliki kewenangan dalam bidang penyelenggaraan untuk mensejahterakan masyarakat desa dengan memberikan dana bantuan berupa alokasi dana desa (ADD).

Alokasi dana desa adalah anggaran keuangan yang diberikan pemerintah kepada desa, yang mana sumbernya berasal dari bagi hasil pajak daerah serta dari dana perimbangan keungan pusat dan daerah yang diterima oleh kabupaten. Sesuai dengan Peraturan Menteri Dalam Negeri No. 7 tahun 2007 Tenatng Pedoman Pengelolaan Keuangan Desa di dalam Pasal 18 menyatakan bahwa "Alokasi Dana Desa berasal dari APBD Kabupaten/Kota yang bersumber dari Dana Perimbangan Keungan Pusat dan Daerah yang diterima oleh Pemerintah Kabupaten / Kota untuk desa sedikitnya 10\%". Selain dana desa tersebut, sesuai dengan UU Nomber 6 tentang Desa pasal 72, desa juga mengeluarkan keungan yang berasal dari Pendapatan Asli Desa dan penapatan Tranfer lainnya berupa Alokasi Dana Desa (ADD), bagian dari Hasil Pajak dan Retribusi Kabupaten / Kota dan Bantuan Keungan dari APBD Provensi/Kabupaten/ kota

Dalam mengelola alokasi dana desa dari pemerintah, bagi hasil pajak dan retribusi daerah, bantuan keugan provensi serta pendapatan asli daerah (PADes), pemerintah desa kini telah bisa menerapkan aplikasi sistem Siskuedes dalam mengelolaan semua keuangan yang masuk. Aplikasi Sistem Keuangan Desa (SISKEUDES) merupakan aplikasi yang dikembangkan Badan Pengawasan Keuangan dan Pembangunan (BPKP) dalam rangka meningkatkan kualitas tata kelola keuangan desa. Dasar pengembangan aplikasi SISKUEDES ini yaitu : UU Nomor 6 Tahun 2014 tentang Desa, PP Nomor 43 Tahun 2014 juncto PP Nomber 47 Tahun 2015 tentang Peraturan Pelaksanaan UU Nomor 6

Tahun 2014 tentang Desa, PP Nomor 60 Tahun 2014 juncto PP Nomor 22 Tahun 2015 tentang Dana Desa yang Bersumber dari APBN, Permendagri Nomor 13 Tahun 2014 tentang Pengelolaan Keungan Desa, Permendagri Nomber 14 Tahun 2014 tentang Pedoman Pembangunan Desa dan PMK Nomor 247 Tahun 2015 tentang Tata Cara 
Pengalokasian, Penyaluran, Penggunaan, Pemantauan dan Evaluasi Dana Desa.

Dengan begitu besar dan banyaknya dana yang masuk ke desa untuk pembagunan dan kesejahteraan masyarakat, pada kenyataannya menimbulkan sedikit masalah bagi beberapa Kantor Kepala di Kecamatan Sawan. Dalam kasus ini keresediaan sumber daya manusia dalam kantor belum memadai, hal ini berakibat pada kesulitan mereka dalam menjalankan aplikasi sistem SISKEUDES. Disisi lain perubahan pagu anggaran dari kabupaten yang terus mengalami perubahaan membuat mereka menjadi kesulitan dalam menyusun anggaran dan berdampak pada pencairan dana desa yang terlambat.

Berdasarkan permasalahan diatas, maka rumusan masalah diatas yaitu bagaimana pengaruh ketersediaan kapasitas SDM dan personalia Kantor Kepala Desa di Kecamatan Sawan terhadap kualitas kinerja karyawan secara keseluruhan, dan bagaimana pengaruh perubahaan Regulasi Pagu Anggaran dari Kabupaten terhadap Anggaran yang telah disusun sebelumnya pada Kantor Kepala Desa di Kecamatan Sawan.

Sejak tahun 2015, pemerintahan desa mulai mengelola dana yang besar lantaran pemerintah $\mathrm{Rl}$ menggelontorkan sejumlah uang lewat dana desa untuk menstimulasi pembangunan ekonomi, serta sarana-prasarana pedesaan.

Dana desa setiap tahunnya bertambah dan tahun Tahun 2017 ini pemerintah pusat menganggarkan dana sebesar Rp60 Triliun, yang akan diberikan untuk 74.954 desa se-Indonesia. Ditengah kegembiraan masyarakat desa yang merasakan secara langsung dampak pembangunan yang besar di desanya, berbagai pihak mulai merasakan kekhawatiran bakal banyaknya kepala desa yang bakal tersangkut masalah hukum akibat salah pelaporan keuangan. Wajar saja banyak yang khawatir, karena kepala desa yang berperan aktif dan secara langsung menyaksikan serta menerima sejumlah uang dalam rangka membangun desanya.

Pemerintah juga merasa khawatir, jika pemerintahan desa tidak diajarkan cara membuat pelaporan yang benar, maka bukan tidak mungkin akan banyak kepala desa yang terkait persoalan hukum. Bukannya dana desa menjadi berkah, malahan uang tersebut bisa menjadi bencana bagi masyarakat pedesaan.

Wakil ketua komisi XI DPR RI, Ahmad Hafisz Tohir mengatakan, kekhawatiran itu sangat beralasan. Lantaran juga pemerintahan desa belum paham dengan paham dengan sistem keuangan yang digunakan. "Bisa dibayangkan jika hal ini terjadi pada seluruh desa yang berjumlah hampir 75 ribu desa. Atas hal tersebut,berbagai stakeholder terkait menyampaikan perlunya BPKP untuk turut serta melakukan pengawalan atas pengelolaan keuangan desa tersebut," terang Hafisz Tohir.

Menurut dia, hal ini disampaikan oleh Presiden pada saat memberikan arahan para Rakornas Pengawasan Internal Tahun 2015, anggota DPR Komisi XI pada saat RDP tanggal 30 Maret dan 10 Mei 2015 lalu, bahkan berdasarkan hasil kajian dari KPK.

Menjawab hal tersebut, salah satu langkah yang dilakukan oleh BPKP adalah dengan mengembangkan aplikasi Siskeudes bekerjasama dengan 
Kementerian Dalam Negeri. Yang kemudian dibuatkan MoU antara Menteri Dalam Negeri dan BPKP pada tanggal 6 November 2015 serta diterbitkannya Surat Edaran Menteri Dalam Negeri tgl 27 November 2015 Bahwa Aplikasi Siskeudes sebagai aplikasi tata kelola keuangan Desa utk seluruh desa yg penerapannya secara bertahap mulai tahun 2016. Aplikasi Siskeudes dikembangkan berdasarkan peraturan yaitu Permendagri Nomor 113 tahun 2014 tentang Pengelolaan Keuangan Desa. "Aplikasi Siskeudes diharapkan dapat membantu Kepala Desa memudahkan tata kelola seluruh sumber penerimaan yang diperoleh pemerintah desa. Dengan sekali melakukan entri, pemerintah desa dapat menghasilkan pelaporan maupun dokumen yang digunakan dalam penatausahaan desa, "terang Hafisz.

Aplikasi ini berbasis komputerisasi. Selain memiliki tampilan yang mudah digunakan, juga dilengkapi dengan Petunjuk Pelaksanaan Implementasi maupun manual aplikasi, mengingat penggunanya memiliki rentang kemampuan yang berbeda-beda. Aplikasi siskeudes ini juga dibangun dengan builtin internal control sehingga kesalahan-kesalahan yang terjadi juga dapat diminimalisir. Dan hal yang sangat ditekankan, aplikasi ini dapat diperoleh secara "gratis" oleh pemerintah desa.

Adapun keluaran aplikasi Siskeudes antara lain, dokumen Perencanaan berupa Rencana Pembangunan Jangka Menengah Desa (RPJM Desa) dan Rencana Kerja Pembangunan Desa (RKP Desa), Dokumen Penganggaran berupa Anggaran Pendapatan dan Belanja Desa (APB Desa), Rincian Anggaran Pendapatan, Rincian.

Anggaran Belanja (RAB), Dokumen Penatausahaan berupa Buku Kas Umum, Buku Bank, Buku Pajak, Buku Rincian Pendapatan, Buku Rincian Pembiayaan, Buku Kas Pembantu Kegiatan, dan bukti transaksi), Laporan-laporan berupa Laporan Realisasi APB Desa, Laporan Kekayaan Milik Desa, Laporan Realisasi per Sumber Dana, dan laporan kompilasi tingkat kabupaten/kota, baik laporan kompilasi Dana Desa yang menjadi syarat pencairan Dana Desa maupun laporan kompilasi realisasi pertanggungjawaban pelaksanaan APBDes yang menjadi lampiran Laporan Keuangan Pemda."Sampai dengan 30 September 2017, aplikasi Siskeudes telah diterapakan secara penuh di 46.001 desa di seluruh Indonesia atau $61,37 \%$ Desa. Secara ekonomis, dengan aplikasi yang bersifat gratis ini kepada seluruh desa, maka desa tidak perlu mengeluarkan dana untuk membeli aplikasi," kata dia.

Hal ini juga sangat efektif mengurangi beban besa membayar konsultan keuangan. Karena rata-rata dana yang dikeluarkan untuk membayar pihak ketiga senilai Rp15 hingga Rp45juta. Jika dirata-ratakan harga aplikasi sebesar $\mathrm{Rp} 15$ juta, maka terdapat dengan potensi penghematan sebesar Rp 1.124.310.000.000,00 (74.954 desa @ Rp15 juta), itupun jika seluruh desa di Indonesia mengimplementasikan Siskeudes. Perubahan Rincian Dana Desa Menurut Daerah Kabupaten/Kota Tahun Anggaran 2018, Undang-Undang Desa telah menempatkan desa sebagai ujung tombak pembangunan dan peningkatan kesejahteraan masyarakat. Desa diberikan kewenangan dan sumber dana yang memadai agar dapat mengelola potensi yang dimilikinya guna 
meningkatkan ekonomi dan kesejahtaraan masyarakat. Setiap tahun Pemerintah Pusat telah menganggarkan Dana Desa yang cukup besar untuk diberikan kepada Desa. Pada tahun 2015, Dana Desa dianggarkan sebesar Rp20,7 triliun, dengan rata-rata setiap desa mendapatkan alokasi sebesar Rp280 juta. Pada tahun 2016, Dana Desa meningkat menjadi Rp46,98 triliun dengan rata-rata setiap desa sebesar Rp628 juta dan di tahun 2017 kembali meningkat menjadi Rp 60 Triliun dengan rata-rata setiap desa sebesar Rp800 juta. Kebijakan pengalokasian Dana Desa TA 2018 dilakukan dengan menyempurnakan formula pengalokasian Dana Desa, melalui:

a. penyesuaian proporsi dana yang dibagi rata (Alokasi Dasar) dan dana yang dibagi berdasarkan formula (Alokasi Formula)

b. memberikan afirmasi pada desa tertinggal dan sangat tertinggal yang mempunyai jumlah penduduk miskin tinggi

c. Memberikan fokus yang lebih besar pada pengentasan kemiskinan dan ketimpangan, yaitu dengan melakukan penyesuaian bobot variabel jumlah penduduk miskin dan luas wilayah.

Dana Desa TA 2018 telah dialokasikan sebesar Rp60.000,00 miliar kepada 74.958 desa, dengan ketentuan sebagai berikut :

a. Alokasi Dasar (AD), sebesar 77\% dari pagu atau sebesar Rp46.200,00 miliar, dibagi secara merata kepada setiap desa.

b. Alokasi Afirmasi (AA), sebesar $3 \%$ dari pagu atau $R p 1.800,00$ miliar, dibagi secara proporsional kepada desa tertinggal dan desa sangat tertinggal yang mempunyai jumlah penduduk miskin (JPM) tinggi

c. Alokasi Formula (AF), sebesar $20 \%$ dari pagu atau Rp12.000,00 miliar, dibagi berdasarkan:

1) jumlah penduduk desa dengan bobot $10 \%$,

2) jumlah penduduk miskin desa dengan bobot $50 \%$,

3) luas wilayah desa dengan bobot 15\%, dan

4) Indeks Kemahalan Konstruksi atau Indeks Kesulitan Geografis desa dengan bobot $25 \%$.

Desa tertinggal dan desa sangat tertinggal dengan jumlah penduduk miskin (JPM) tinggi adalah desa tertinggal dan desa sangat tertinggal yang memiliki jumlah penduduk miskin (JPM) terbanyak yang berada pada kelompok desa pada desil ke 8, 9, dan 10.

Data yang digunakan untuk penghitungan Dana Desa bersumber dari BPS dan/atau Kementerian/Lembaga yang sesuai kewenangannya berwenang menerbitkan data yang dapat dipertanggungjawabkan. Dalam hal data tidak tersedia, perhitungan Dana Desa menggunakan data tahun sebelumnya dan/atau menggunakan rata-rata data desa dalam satu kecamatan dimana desa tersebut berada. Data Dana Desa terdiri dari :

a. Jumlah Desa, yang bersumber dari Kementerian Dalam Negeri

b. Jumlah Penduduk (JP) Desa, yang bersumber dari data kependudukan dan catatan sipil (dukcapil) Kementerian Dalam Negeri.

c. Jumlah Penduduk Miskin (JPM) Desa, yang bersumber dari

d. Kementerian social 
e. Luas wilayah (LW) Desa, yang bersumber dari BPS

f. Status Desa, yang bersumber dari data indeks desa membangun Kementerian Desa dan PDTT.

Berdasarkan Undang-Undang Nomor 15 Tahun 2017 tentang Anggaran Pendapatan dan Belanja Negara Tahun Anggaran 2018 dan Peraturan Presiden Nomor 107 Tahun 2017 tentang Rincian Anggaran Pendapatan dan Belanja Negara Tahun Anggaran 2018 telah ditetapkan rincian Dana Desa menurut kabupaten/kota Tahun Anggaran 2018.

Bahwa berdasarkan perubahan data status Desa yang bersumber dari data Indeks Desa Membangun Kementerian Desa, Pembangunan Daerah Tertinggal, dan Transmigrasi, perlu dilakukan perubahan rincian Dana Desa menurut kabupaten/kota TA 2018 melalui penetapan Peraturan Menteri Keuangan. Hal tersebut sesuai dengan ketentuan Pasal 5 ayat (3) huruf a Peraturan Presiden Nomor 107 Tahun 2017 tentang Rincian Anggaran Pendapatan dan Belanja Negara Tahun Anggaran 2018 yang menyatakan bahwa perubahan rincian Dana Desa menurut kabupaten/kota sebagai akibat dari perubahan data ditetapkan dengan Peraturan Menteri Keuangan.

Komponen Anggaran Desa

\section{Pendapatan}

Menurut Permendagri No 113 Tahun 2014 Pendapatan Desa meliputi semua penerimaan uang melalui rekening desa yang merupakan hak desa dalam 1 tahun anggaran yang tidak perlu dibayar kembali oleh desa. Pendapatan desa dapat berasal dari:

\section{a. Pendapatan Asli Desa}

Hasil usaha desa. Contoh desa mempunyai badan usaha milik desa (Bumdes) bidang usaha pembuatan batik, hasilnya masuk dalam hasil usaha desa.

Hasil kekayaan desa. Contoh tanah kas desa, pasar desa, bangunan desa, wisata yang dikelola desa, pemandian desa, hutan desa, dll.

Hasil swadaya dan partisipasi masyarakat adalah membangun dengan kekuatan sendiri yang melibatkan peran serta masyarakat berupa tenaga atau barang yang dinilai dengan uang, contoh: urunan desa, urunan carik, iuran penitipan kendaraan.

Lain-lain pendapatan asli desa. Contoh ganti ongkos cetak suratsurat, biaya legalisasi surat-surat, sewa tanah desa.

b. Transfer

Dana Desa adalah sumber dana yang berasal dari anggaran pendapatan dan belanja negara ditransfer melalui anggaran pendapatan dan belanja daerah Kabupaten/Kota dan digunakan untuk Jurnal IImiah Akuntansi dan Humanika | 179 
menyelenggarakan pemerintahan, pembangunan desa, pembinaan, dan pemberdayaan masyarakat.

Bagi hasil pajak daerah Kabupaten/Kota dan retribusi daerah.

Misalnya: bagi hasil pajak bumi dan bangunan.

Alokasi Dana Desa (ADD) adalah dana yang dialokasikan oleh kabupaten untuk desa. Sumber ADD ini adalah dana perimbangan pusat dan daerah yang diterima kabupaten untuk desa.

Bantuan keuangan APBD Pem.Prop, Kab/Kota b.

Kelompok pendapatan lain-lain, jenis:

Hibah dan sumbangan pihak ketiga yang tidak mengikat dapat berbentuk hadiah, donasi, wakaf, hibah atau sumbangan lain. Sumbangan yang berbentuk barang (bergerak maupun tidak bergerak) dicatat sebagai barang inventaris kekayaan milik desa sesuai UU, dapat juga berbentuk uang, tetapi tidak mengikat.

Lain-lain pendapatan desa yang sah, antara lain hasil kerjasama dengan pihak ketiga, bantuan perusahaan yang berlokasi di desa.

\section{Belanja Desa}

Menurut Permendagri No 113 Tahun 2014 belanja desa meliputi semua pengeluaran dari rekening desa yang merupakan kewajiban desa dalam 1 tahun anggaran yang tidak akan diperoleh pembayarannya kembali oleh desa. Belanja desa dipergunakan dalam rangka mendanai penyelenggaraan kewenangan desa. Belanja desa terdiri dari:

\section{a. Belanja Bidang Penyelenggaraan Pemerintah Desa}

Belanja ini meliputi beberapa jenis yaitu:

Penghasilan tetap dan tunjangan, ini terdiri dari belanja pegawai (penghasilan tetap kepala desa, tunjangan kepala desa, tunjagan BPD).

Operasional perkantoran terdiri dari: (i) Belanja barang dan jasa, misalnya belanja alat tulis kantor, benda pos, bahan/material, pemeliharaan, cetak/penggandaan, sewa kantor desa, sewa perlengkapan dan peralatan kantor, makanan dan minuman rapat, pakaian dinas dana atributnya, perjalanan dinas, upah kerja, honorarium narasumber/ahli, operasional Pemerintah Desa, opersional BPD, insentif Rukun Tetangga/Rukun Warga (bantuan untuk opersional lembaga RT/RW dalam rangka membantu pelaksanaan tugas pelayanan pemerintahan, perencanaan pembangunan, ketentraman dan ketertiban, serta 
pemberdayaan masyarakat desa), dan pemberian barang pada masyarakat/kelompok masyarakat dilakukan untuk menunjang pelaksanaan kegiatan. (ii) Belanja modal digunakan untuk pengeluaran dalam rangka pembelian/pengadaan barang atau bangunan yang nilai manfaatnya lebih dari 12 (dua belas) bulan. Pembelian/pengadaan barang atau bangunan digunakan untuk kegiatan penyelenggaraan kewenangan desa, misalnya: beli komputer, beli meja.

\section{b. Bidang Pelaksanaan Pembangunan Desa}

Belanja jenis ini merupakan belanja yang digunakan untuk pembangunan desa, contoh perbaikan saluran irigasi, pengaspalan jalan, dll.

\section{c. Bidang Pembinaan Kemasyarakatan}

Belanja jenis ini digunakan untuk pembinaan masyarakat desa, misalnya pendanaan untuk pelatihan perangkat desa, pendanaan untuk kegiatan taruna.

\section{d. Bidang Pemberdayaan Masyarakat}

Belanja jenis ini digunakan untuk pemberdayaan masyarakat desa, misalnya pendanaan untuk pengelolaan lingkungan hidup, pengelolaan sampah mandiri.

\section{e. Bidang Tak Terduga}

Belanja ini digunakan untuk hal-hal yang tidak terduga. Kegiatan dalam keadaan darurat dianggarkan dalam belanja tidak terduga, misalnya kegiatan sosial bencana.

\section{Pembiayaan}

Menurut Permendagri No 113 Tahun 2014 Pembiayaan Desa meliputi semua penerimaan yang perlu dibayar kembali dan/atau pengeluaran yang akan diterima kembali, baik pada tahun anggaran yang bersangkutan maupun pada tahun-tahun anggaran berikutnya. Pembiayaan terdiri dari:

\section{a. Penerimaan pembiayaan mencakup:}

Sisa lebih perhitungan anggaran (Silpa) tahun sebelumnya

Mencakup pelampauan penerimaan pendapatan terhadap belanja, penghematan belanja, sisa dana kegiatan lanjutan. Hal tersebut seperti kelebihan penerimaan pendapatan asli desa, kelebihan penerimaan alokasi dana desa, kelebihan penerimaan lain-lain, kelebihan penerimaan pembiayaan, penghematan belanja, sisa 
dana kegiatan. Silpa juga merupakan sisa lebih tahun anggaran sebelumnya. Silpa menutupi defisit anggaran apabila realisasi pendapatanb lebih kecil daripada realisasi belanja, mendanai pelaksanaan kegiatan lanjutan, dan mendanai kewajiban lainnya yang sampai dengan akhir tahun anggaran belum diselesaikan.

Pencairan dana cadangan digunakan untuk menganggarkan pencairan dana cadangan dari rekening dana cadangan ke rekening kas desa dalam tahun anggaran berkenaan. Dana cadangan tidak dapat digunakan untuk membiayai kegiatan di luar yang sudah ditetapkan sebelumnya dalam peraturan desa tentang pembentukan dana cadangan.

Hasil penjualan kekayaan desa yang dipisahkan digunakan untuk menganggarkan hasil penjualan kekayaan desa yang dipisahkan.

Penerimaan pinjaman

b. Pengeluaran pembiayaan mencakup:

Pembentukan dan penambahan dana cadangan digunakan untuk membiayai kegiatan yang sudah ditetapkan dalam pembentukan dana cadangan. Dana cadangan tidak dapat sekaligus dibebankan dalam 1 tahun anggaran yang ditetapkan dalam peraturan desa. Pembentukan dana cadangan ditetapkan dengan peraturan desa, paling sedikit memuat: penetapan tujuan pembentukan dan cadangan, program dan kegiatan yang akan dibiayai dari dana cadangan, besaran dan rincian tahunan dana cadangan yang harus dianggarkan, sumber dana cadangan, dan tahun anggaran pelaksanaan dana cadangan. Pembentukan dana cadangan dapat bersumber dari penyisihan atas penerimaan desa, kecuali dari penerimaan yang penggunaannya telah ditentukan secara khusus berdasarkan peraturan perundang-undangan. Pembentukan dana cadangan ditempatkan pada rekening tersendiri. Penganggaran dana cadangan tidak melebihi tahun akhir masa jabatan Kepala Desa.

Penyertaan modal desa. Pemerintah desa dapat melakukan investasi pada Bumdes ( Badan Usaha Milik Desa) atau badan swasta lain. Penyertaan modal ini dilakukan oleh kepala desa dan disetujui BPD setelah ada ketetapan peraturan desa. Penyertaan modal desa masuk dalam pengeluaraan pembiayaan dan digunakan untuk menganggarkan kekayaan pemerintah desa yang diinvestasikan baik jangka pendek maupun jangka panjang.

Pembayaran hutang. Pembayaran kewajiban desa yang timbul akibat pinjaman desa pada pihak lain.

Faktor Yang Mempengaruhi Hasil Kinerja 
Ternyata, ada beragam faktor yang mempengaruhi kinerja karyawan, dan hal ini penting untuk diketahui oleh Anda yang berprofesi sebagai HR. Sebelum menciptakan inovasi dalam bidang human asset development, ada baiknya Anda melakukan evaluasi terlebih dahulu. Ketika Anda mengoptimalkan faktor-faktor tersebut, maka diharapkan akan muncul dampak positif pula. Berikut tujuh faktor yang mempengaruhi kinerja karyawan:

\section{Ketersediaan Peralatan dan Barang}

Anda berharap departemen Layanan Pelanggan dapat melayani pelanggan dalam waktu yang sesegera mungkin, tapi tidak membekali mereka dengan internet kecepatan tinggi atau perangkat telepon yang mumpuni? Mustahil! Anda ingin menciptakan suasana kerja yang nyaman, tapi tidak menyediakan pendingin ruangan atau dispenser air minum? Tidak mungkin! Selain mesin-mesin yang berhubungan dengan proses produksi, sebagian barang mutlak dibutuhkan untuk menunjang kelancaran tugas karyawan. Contoh lain, daripada karyawan bolak-balik keluar kantor untuk fotokopi, pertimbangkan untuk memiliki mesin fotokopi.

\section{Lingkungan Kerja}

Memastikan karyawan memiliki tempat kerja yang 'sehat' adalah kunci dari produktivitas karyawan. Sebagaimana disebutkan pada poin di atas, Anda seharusnya tahu ruangan kantor yang selaras memenuhi kaidah pencahayaan dan sirkulasi udara. Sebagian besar karyawan juga dapat menilai perusahaan dari kubikel, toilet, pantry, tempat ibadah, dan ruang istirahat yang disediakan. Apakah Anda sudah memberikan yang terbaik untuk memastikan karyawan dapat berkonsentrasi pada pekerjaannya?

\section{Job Description dan Tanggung Jawab}

Seringkali produktivitas karyawan mengalami stagnasi karena ia merasa jenuh atau bosan pada pekerjaannya. HR dapat meyakinkan karyawan tentang kontribusi yang telah mereka hasilkan untuk perusahaan, sehingga motivasi mereka kembali meningkat. Selain itu, menempatkan karyawan pada tim kerja yang tepat, atau mempercayakan proyek khusus, akan menghadirkan minat dan perhatian mereka. Intinya adalah menyadarkan bahwa keberadaan setiap karyawan berharga dan masing-masing memiliki peran terhadap keberhasilan perusahaan.

4. Visi, Misi, dan Budaya Organisas

Angkatan kerja generasi millennial selalu mencari 'purpose' atau 'the meaning of life'. Mereka bekerja untuk menciptakan suatu perubahan pada masyarakat, dan mereka bangga bergabung dengan 
perusahaan yang memberikan mereka ruang untuk berkarya. Apakah Anda sudah pernahmen sosialisasikan tentang hal ini kepada karyawan Anda?

\section{Sistem Komunikasi dan Cara Kerja Pimpinan}

Saat karyawan menghadapi permasalahan, kemana ia harus melapor? Siapa yang bertugas untuk membantunya mencari solusi? Apakah para atasan, supervisor, dan manajemen sudah cukup tanggap dan terbuka? Atau karyawan justru merasa segan dan takut? Majalah bisnis 'Entrepreneur' mendapati bahwa karyawan mengharapkan bos yang suportif, yaitu memiliki karakter: pengertian, fleksibel, dan dapat dipercaya. Hal ini akan mempengaruhi bagaimana karyawan berinteraksi dan berkomunikasi dalam pekerjaannya.

\section{Pelatihan dan Pengembangan Diri}

Jika Anda ingin karyawan semakin handal dalam pekerjaannya, pelatihan adalah solusi terbaik! Di samping menambah wawasan, pelatihan dapat menyegarkan pikiran dan mengurangi ketegangan.

\section{Bonus dan Insentif}

Tak dapat dipungkiri, upah merupakan salah satu faktor paling krusial dalam upaya meningkatkan motivasi kerja karyawan. Selain gaji pokok dan tunjangan tetap, HR harus kreatif dalam merancang paket benefit agar kinerja karyawan tetap terjaga, seperti memberikan bonus dan insentif kepada karyawan maupun tim kerja yang telah mencapai target perusahaan. Manfaatkan HR software untuk melakukan perhitungan gaji, lembur, THR; hingga BPJS dan PPh 21. Dengan aplikasi HR Gadjian, penggajian akan menjadi lebih efisien dan transparan. Gadjian pun menyediakan slip gaji online yang bisa diakses oleh karyawan yang bersangkutan.

Cara paling mudah untuk melihat kinerja karyawan adalah

dengan memantau kehadirannya. Ketika karyawan mulai sering izin atau terlambat, dapat diprediksi kalau kinerjanya akan bermasalah. Akan tetapi, bagaimana memonitor kehadiran karyawan di lokasi yang tersebar atau memiliki mobilitas tinggi? Tenang, ada aplikasi absensi Hadir yang dapat mencatat absensi karyawan secara real time. Hadirr juga dapat digunakan untuk mengelola reimbursement. Praktis dan mudah.

\section{Motodologi Penelitian}

Penelitian yang digunakan dalam penelitian ini adalah penelitian kuantitatif. Suharsimi (2006: 12) mengemukakan bahwa, "Penelitian kuantitatif banyak 
menggunakan angka, mulai dari pengumpulan data, penafsiran terhadap data tersebut, serta penampilan dari hasilnya".

Objek penelitian merupakan sesuatu yang menjadi perhatian dalam suatu penelitian, objek penelitian ini menjadi sasaran dalam penelitian untuk mendapatkan jawaban ataupun solusi dari permasalahan yang terjadi. Adapun pengertian objek penelitian menurut Sugiyono (2012:13) adalah sasaran ilmiah untuk mendapatkan data dengan tujuan dan kegunaan tertentu tentang sesuatu hal objektif, valid, dan reliable tentang suatu hal (variabel tertentu)". Sementara itu menurut Suharsini Arikunto (1998: 15) objek penelitian adalah variable atau apa yang menjadi titik perhatian suatu penelitian, sedangkan subjek penelitian merupakan tempat dimana variable melekat. Objek dari penelitian ini adalah ketersediaan sumber daya manusia dalam mengoprasikan system SISKEUDES dan regulasi terhadap pagu agnggaran. Lokasi penelitian dilakukan di 5 kantor kepala desa yang berada Kecamatan Sawan, yaitu kantor kepala Desa Jagaraga, kantor kepala Desa Menyali, kantor kepala Desa Sawan, kantor kepala Desa Bebetin, dan kantor kepala Desa Sekumpul. Populasi dalam penelitian ini adalah seluruh pegawai kantor kepala desa yang telah disebutkan tadi, tetapi hanya 30 pegawai yang digunakan sebagai sampel.

Teknik Pengambilan sampel yang digunakan adalah pengambilan sampel acak sederhana disebut juga Simple Random Sampling. (Sugiyono, 2001: 56). Menyatakan bahwa "metode pengambilan sampel acak sederhana adalah teknik penarikan sampel menggunakan cara ini memberikan kesempatan yang sama bagi setiap anggota populasi untuk menjadi sampel penelitian.

Metode pengumpulan data yang digunakan adalah angket/kuesioner, wawancara dan observasi. Suharsimi (2006:151) mengungkapkan, "Metode angket atau kuisioner adalah sejumlah pertanyaan tertulis yang dipergunakan untuk memperoleh informasi dari responden dalam arti laporan tentang pribadinya, atau hal-hal yang diketahui". Angket/kuesioner dalam penelitian ini adalah terdiri dari butir-butir pernyataan yang digunakan untuk mengumpulkan data yang berkaitan dengan pemahaman karyawan kantor kepala desa terhadap aplikasi SISKEUDES dan pengaruh perubahan regulasi anggaran terhadap kinerja karyawan.

Arikunto (2006 : 230) menyatakan, "Metode observasi atau mengamati adalah menatap kejadian, gerak atau proses". Dalam penelitian ini juga menggunakan metode wawancara untuk mendapatkan informasi/data yang relevan. "metode wawancara adalah percakapan dengan maksud tertentu" (Moeleong,2006:186). Wawancara itu dilakukan oleh dua pihak, yaitu pewawancara (interviewer) yang mengajukan pertanyaan dan terwawancara (unterviewee) yang memberikan jawaban atas pertanyaan itu. wawancara yang digunakan dalam penelitian ini adalah wawancara tidak terstuktur, yaitu wawancara yang tidak berpedoman pada daftar pertanyaan. 


\subsection{Hasil dan Pembahasan}

Pengaruh Ketersediaan Kapasitas SDM Dan Personalia Kantor Kepala Desa Di Kecamatan Sawan Terhadap Kualitas Kinerja Karyawan Secara Keseluruhan Penelitian dilakukan melalui wawancara serta mengisi kuisioner untuk mengetahui apakah terdapat pengaruh dari ketersediaan kapasitas SDM dan personalia kantor kepala desa di kecamatan sawan terhadap kualitas kinerja karyawan secara keseluruhan. Kualitas kinerja yang dimaksud yaitu dalam hal kemampuan menggunakan SISKEUDES dalam melakukan pekerjaan. Penelitian ini dilakukan di kantor kepala desa di wilayah Kecamatan Sawan, untuk sample yaitu sebanyak 7 orang pegawai di masing - masing kantor kepala desa.

Kuisioner berisi pernyataan mengenai ketersediaan kapasitas SDM dan Personalia yang ada hingga penggunaan SISKEUDES di kantor desa di wilayah Kecamatan Sawan. Adapun pernyataan yang diajukan dalam kuisioner :

a. Ketersediaan Listrik di Kantor Kepala Desa belum memadai

b. Ketersediaan sarana Komputer/Laptop di Kantor Kepala Desa belum memadai

c. Aplikasi SISKEUDES sulit dioperasikan

d. Aplikasi SISKEUDES kurang membantu pekerjaan anda

e. Data yang dihasilkan aplikasi SISKEUDES belum tepat/akurat

Setiap pernyataan dijawab dengan memberikan tanda centang $(\sqrt{ })$ pada kolom pilihan yang terdiri atas : Sangat Setuju, Setuju, Kurang Setuju, Tidak Setuju, dan Sangat Tidak Setuju. Masing - masing pilihan jawaban memiliki skor masing - masing. Rincian skor dari setiap pilihan jawaban yaitu:

$\begin{array}{ll}\text { Sangat Setuju (SS) } & =5 \\ \text { Setuju (S) } & =4 \\ \text { Kurang Setuju (KS) } & =3 \\ \text { Tidak Setuju (TS) } & =2 \\ \text { Sangat Tidak Setuju (STS) } & =1\end{array}$

Berdasarkan persentase jawaban responden di 5 kantor kepala desa pada masing-masing pertanyaan dalam kuisioner untuk menghitung persentase kelompok responden dan dapat ditampilkan dalam bentuk grafik, maka digunakan

Skor Ideal $($ SMax $)=5 \times n=5 n(S S)$ 
Skor Terendah (SMin) $=1 \times n=1 \mathrm{n}$ (STS), dimana $\mathrm{n}=$ total responden

Skor $=\sum$ (Jumlah responden pemilih $\mathrm{x}$ skor jawaban $)$

Presentasi interpretasi $(P)=($ Skor : SMax $) \times 100 \%$

Setiap jawaban dari masing - masing responden akan di akumulasikan dan dikelompokkan menjadi 5 kelompok sesuai dengan kantor desanya masing masing.

Hasil skoring pada responden pegawai kantor desa terhadap setiap pernyataan $(P)$ yang didapat dari perhitungan yang telah dirumuskan yaitu sebagai berikut :

\begin{tabular}{|l|l|l|l|l|l|l|}
\hline No. & Kantor Desa & P1 & P2 & P3 & P4 & P5 \\
\hline 1 & Desa Jagaraga & 21 & 10 & 33 & 25 & 21 \\
\hline 2 & Desa Menyali & 28 & 11 & 25 & 21 & 28 \\
\hline 3 & Desa Sawan & 28 & 14 & 37 & 25 & 21 \\
\hline 4 & Desa Bebetin & 18 & 8 & 33 & 15 & 26 \\
\hline 5 & Desa Bebetin & 19 & 10 & 28 & 24 & 28 \\
\hline & Jumlah skor & 114 & 53 & 156 & 110 & 124 \\
\hline & Skor Max & 175 & 175 & 175 & 175 & 175 \\
\hline & Persentase & $65 \%$ & $30 \%$ & $89 \%$ & $63 \%$ & $70 \%$ \\
& & & & & & \\
\hline
\end{tabular}

Hasil perhitungan dari tabel diatas, maka dapat dipresentasikan ke dalam grafik seperti berikut :

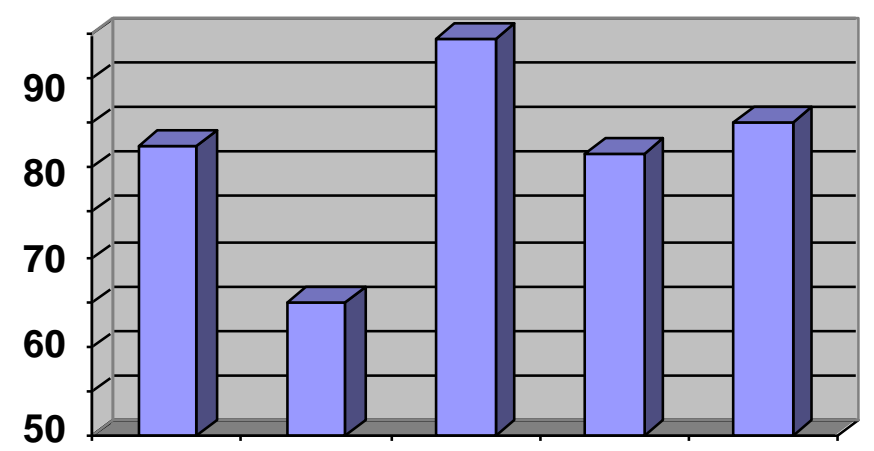


0

\section{$\begin{array}{lllll}\text { P1 } & \text { P2 } & \text { P3 } & \text { P4 } & \text { P5 }\end{array}$}

Berdasarkan hasil tersebut, dapat dikatakan bahwa kualitas SDM dan Personalia dapat berpengaruh terhadap kinerja karyawan. Dilihat pada grafik, P3 yaitu tentang kesulitan dalam menggunakan SISKEUDES memiliki presentasi tertinggi yaitu sebanyak $89 \%$ yang berarti bahwa tingkat pengetahuan dan keahlian pegawai desa dalam menggunakan SISKEUDES masih kurang sehingga berpengaruh terhadap kinerja di kantor desa itu sendiri. Pengaruh tersebut dapat dilihat pada P5 yaitu pernyataan mengenai keakuratan informasi yang dihasilkan SISKEUDES yang memiliki presentase yang terbilang tinggi yaitu $70 \%$. Kurangnya kemampuan pegawai dalam menggunakan SISKEUDES berdampak terhadap akuratnya data yang dihasilkan.

Pengaruh perubahaan Regulasi Pagu Anggaran dari Kabupaten terhadap Anggaran yang telah disusun sebelumnya pada Kantor Kepala Desa di Kecamatan Sawan Penelitian yang dilakukan dalam masalah ini memiliki metode yang sama dengan rumusan masalah sebelumnya yaitu melalui wawancara serta mengisi kuisioner untuk mengetahui apakah terdapat pengaruh dari perubahaan Regulasi Pagu Anggaran dari Kabupaten terhadap Anggaran yang telah disusun sebelumnya pada Kantor Kepala Desa di Kecamatan Sawan. Kuisioner berisi pernyataan mengenai ketersediaan kapasitas SDM dan Personalia yang ada hingga penggunaan SISKEUDES di kantor desa di wilayah Kecamatan Sawan. Adapun pernyataan yang diajukan dalam kuisioner :

a. PAGU Anggaran yang baru tidak sesuai dengan kebutuhan

b. PAGU Anggaran yang baru tidak memungkinkan dalam pelaksanaan semua program desa

c. PAGU Anggaran yang baru mengubah program kerja sebelumnya $\mathrm{d}$. PAGU Anggaran yang baru menghambat pelaporan anggaran desa

e. PAGU Anggaran yang baru kurang efisien dibandingkan sebelumnya

Setiap pernyataan dijawab dengan memberikan tanda centang $(\sqrt{ })$ pada kolom pilihan yang terdiri atas : Sangat Setuju, Setuju, Kurang Setuju, Tidak Setuju, dan Sangat Tidak Setuju. Masing - masing pilihan jawaban memiliki skor masing - masing. Rincian skor dari setiap pilihan jawaban yaitu: 


$\begin{array}{lll}\text { Sangat Setuju (SS) } & = & 5 \\ \text { Setuju (S) } & = & 4 \\ \text { Kurang Setuju (KS) } & = & 3 \\ \text { Tidak Setuju (TS) } & = & 2\end{array}$

Sangat Tidak Setuju (STS) $=1$

Setiap jawaban dari masing - masing responden akan di akumulasikan dan dikelompokkan menjadi 5 kelompok sesuai dengan kantor desanya masing masing.

Hasil skoring pada responden pegawai kantor desa terhadap setiap pernyataan $(P)$ yang didapat dari perhitungan yang telah dirumuskan yaitu sebagai berikut :

Hasil perhitungan dari tabel diatas, maka dapat dipresentasikan ke dalam grafik seperti berikut :

\begin{tabular}{|l|l|l|l|l|l|l|}
\hline No. & Kantor Desa & P1 & P2 & P3 & P4 & P5 \\
\hline 1 & Desa Jagaraga & 28 & 28 & 32 & 34 & 29 \\
\hline 2 & Desa Menyali & 35 & 29 & 26 & 27 & 28 \\
\hline 3 & Desa Sawan & 34 & 27 & 28 & 26 & 21 \\
\hline 4 & Desa Bebetin & 34 & 35 & 21 & 33 & 27 \\
\hline 5 & Desa Bebetin & 21 & 37 & 33 & 35 & 21 \\
\hline & Jumlah skor & 152 & 156 & 140 & 155 & 126 \\
\hline & Skor Max & 175 & 175 & 175 & 175 & 175 \\
\hline
\end{tabular}

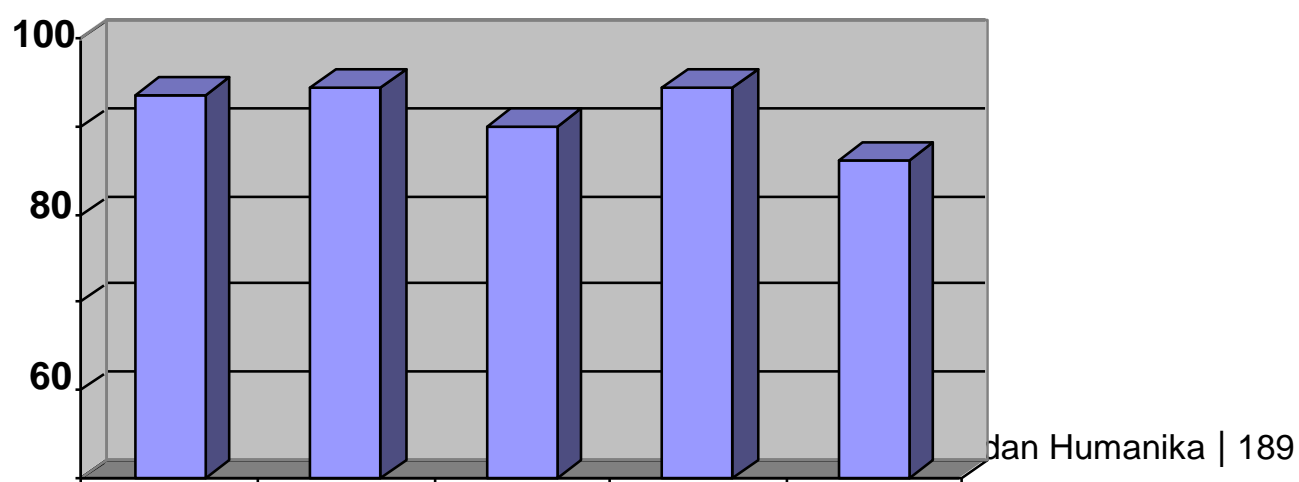


0
P1 P2
P3
P4
P5

Berdasarkan hasil tersebut, dapat dikatakan bahwa perubahan pagu anggaran berpengaruh terhadap anggaran yang telah disusun sebelumnya. Dilihat pada grafik, P2 yaitu tentang kemungkinan menjalankan program desa yang telah disusun memiliki presentasi tertinggi yaitu sebanyak $89 \%$ yang berarti bahwa perubahan PAGU Anggaran yang baru tidak memadai untuk menjalankan semua program kerja yang telah disusun oleh Desa sebelumnya. Selain P2, pernyataan lain juga memiliki presentase yang tinggi yakni diatas $70 \%$ yang menguatkan bahwa perbahaan Regulasi Pagu Anggaran dari Kabupaten berpengaruh terhadap Anggaran yang telah disusun sebelumnya pada Kantor Kepala Desa di wilayah Kecamatan Sawan.

\section{Simpulan dan Saran}

\subsection{Simpulan}

Kualitas SDM dan Personalia dapat berpengaruh terhadap kinerja karyawan. Tingkat pengetahuan dan keahlian pegawai desa dalam menggunakan SISKEUDES masih kurang sehingga berpengaruh terhadap kinerja di kantor desa itu sendiri. Pengaruh tersebut berupa kurangnya keakuratan informasi yang dihasilkan SISKEUDES. Kemampuan pegawai yang masih belum mahir dalam dalam menggunakan SISKEUDES berdampak terhadap akuratnya data yang dihasilkan, sehingga dapat dikatakan bahwa kualitas SDM dan Personalia berpengaruh terhadap kualitas kinerja kantor kepala desa di wilayah Kecamatan Sawan. Sedangkan dalam sisi perubahan PAGU, terdapat pengaruh - pengaruh terhadap jalannya program yang direncakan. Perubahan PAGU Anggaran yang baru juga dikatakan tidak memadai untuk menjalankan semua program kerja yang telah disusun oleh Desa sebelumnya, ini berarti jalannya program Desa akan sedikit terhambat.

\subsection{Saran}


Berdasarkan kesimpulan penelitian, maka penulis merekomendasikan berupa saran-saran sebagai berikut:

1. Untuk meningkatkan kualitas informasi keungan desa yang dihasilkan melalui system SISKEUDES perlu dilakukan pelatiahan bagi pegawai kantor desa, karena pemahaman mereka yang masih kurang dalam dalam pengoprasian system sehingga berdampak terhadap hasil kinerja.

2. Penyusunan anggaran desa harus sesuai dengan pagu anggaran yang ditetapkan kabupaten. Tidak konsistennya pagu anggaran membuat penyusunan aggaran desa juga terhambat. Untuk meningkatkan penyusunan anggran yang efektif pagu anggaran harus ditetapkan terlebihdahulu dan tidak ada perubahan yasignifikan lagi dari pagu anggaran yang ditetapkan kabupaten, hal ini akan berdampak juga bagi penyusunan aggaran desa bias disusun lebih cepat dan tidak ada perubahan anggran lagi pada saat anggran yang terdahulu sudah dijalankan.

\section{Daftar Pustaka}
Anonim. 2011. Definisi Metode Kuisoner . Dalam https://plus.google.com/108778983038189772221/posts/aL7 uEdCPD7L. diakses pada tanggal 5 juni 2018

Anonim. 2013. Pengertian Metode Observasi dan definisi. Dalam http://www.sarjanaku.com/2013/04/pengertian-metode- $\quad$ observasidefinisi.html. Diakses pada tanggal 10 juni 2018

Anonim. 2017. Definisi Penelitian Kuantitatif. Dalam http://www.djpk.kemenkeu.go.id/?p=5800. Diakses pada tanggal 1 juni 2018

Anonim. 2017. Definisi Penelitian Kuantitatif. Dalam http://www.literasiinformasi.com/2017/11/definisi-penelitian-kuantitatif$\underline{\text { menurut.html }}$

Anonim. 2017. Siskeudes dan pembagunan desa. Dalam http://tabloiddesa.com/siskeudes-dan-pembangunan-keuangan-desa/. Diakses pada tanggal 1 juni 2018

Kemenkeu. 2018. Pagu Anggaran Kabupaten. Dalam http://www.djpk.kemenkeu.go.id/?p=5800. Diakses pada tanggal 5 juni 2018

Rayendra. 2015. Teori Metodologi Penelitian. Dalam 
http://rayendar.blogspot.com/2015/12/teori-teori-metodologipenelitian.html. Diakses pada tanggal 10 juni 2018

Tanuwijaya dan Murtono imam. 2017. Artikel Pengaruh Kemampuan Karyawan, Kejelasan Aturan, Kesempatan Berkinerja dan Penghargaan Perusahaan Terhadap Kinerja Karyawan. 